\author{
CONSUELO CARREDANO \\ INSTITUTO DE INVESTIGACIONES ESTÉTICAS
}

\title{
Hasta los verdes maizales de México: Rodolfo Halffter y Don Lindo de Almería
}

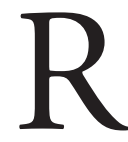
odolfo Halffter compuso la suite del ballet Don Lindo de Almería para el libreto homónimo de José Bergamín, quien originalmente pretendía llevarlo a la escena coreográfica española con música de Manuel de Falla y decorados de Pablo Picasso. Como se sabe, la obra, en su modalidad de ballet, no se estrenaría en la España de la preguerra. No fue sino hasta I940, recién comenzado su exilio mexicano, cuando Halffter y Bergamín lograron presentarla en el Teatro Fábregas con escenografía del pintor Antonio Ruiz y una improvisada compañía de danza integrada para ese fin por la estadounidense Ana Sokolov.

Tres meses antes de estallar la guerra civil tuvo lugar en Barcelona una de las primeras ejecuciones de la obra en versión de concierto. La influyente crítica de Adolfo Salazar — a quien mucho se debía la realización de las XIV Jornadas de la Sociedad Internacional para la Música Contemporánea (SIMC) en España, en cuyo marco se presentó- destacaba ya la singularidad de la obra en el todavía breve catálogo del compositor. Rodolfo Halffter abandonaba las tendencias experimentales que definían sus composiciones iniciales y abrazaba sin reservas los principios de la estética neoclásica, vigente en distintas latitudes y, en España, a partir del modelo impuesto por Falla en obras como El retablo de maese Pedro (1922) y el Concerto para clavicémbalo (I926). Más tarde, el mismo Rodolfo Halffter recordaba aquella "espontánea” adhesión estética y reconocía haber adoptado con absoluta naturalidad 
"dogmas" que representaban todo lo contrario de lo que había creído hasta ese momento. ${ }^{\text {I }}$

La estela que los Ballets Russes dejaron a su paso por España en los años de la primera guerra mundial y posteriores despertó en buen número de escritores, compositores y artistas plásticos el interés por la danza y dio lugar a una verdadera eclosión de obras para el género. ${ }^{2}$ Se ha señalado lo suficiente el efecto que produjo el grupo de Diaghilev entre los jóvenes creadores espańoles en busca de ubicación artística propia y, en sentido inverso, la influencia de España en la metamorfosis de los programas y el estilo de los ballets. La contribución de Picasso a la definición estética de la troupe, en tanto autor de figurines y decorados para algunas coreografías, y la participación de Falla en proyectos relacionados con la compañía rusa y con el mismo Picasso convirtieron a ambos artistas en referentes obligados de la danza espańola. Músico y pintor encarnaron como pocos el ideal de las vanguardias espańolas y, en su caso, de quienes pretendían incursionar en el medio dancístico. ¿Qué joven artista no habría querido entrar por la puerta grande del teatro de la mano de ellos?

El rumbo que tomó el libreto de Don Lindo de Almería antes de encontrar en Halffter su partitura definitiva constituye un episodio interesante que bien vale la pena recoger aquí. Bergamín, de acuerdo con Nigel Dennis — que ha estudiado su obra con profundidad-, es una de las figuras más desconcertantes, difíciles de clasificar y peor comprendidas de las letras españolas del siglo pasado. En los primeros años de la década de 1920 destacaba ya entre los nuevos valores y mostraba una marcada preferencia por el teatro. No obstante, sus primeras piezas tuvieron una tibia acogida por parte del público y de la crítica debido a su acentuado y un tanto "estrafalario" carácter experimental, y por los retos técnicos que planteaba su puesta en escena. Es el mismo crítico quien

I. Rodolfo Halffter, "Manuel de Falla y los compositores del Grupo de Madrid de la Generación del 27”, en Antonio Iglesias, Rodolfo Halffer (su obra para piano), Madrid, Alpuerto, I979, p. 48; después reproducido en Emilio Casares (ed.), La música en la Generación del 27. Homenaje a Lorca (1915-1936), Madrid, Ministerio de Cultura/Instituto Aragonés de Empleo, 1986, y en Xochiquetzal Ruiz Ortiz, Rodolfo Halffter, México, Instituto Nacional de Bellas Artes-Centro Nacional de Investigación e Información Musical Carlos Chávez, I990.

2. Europa entera se deslumbró con aquel espectáculo. Una entre tantas figuras que se dejaron fascinar por los bailarines rusos fue el gran Rilke. Se dice que en I9I I, tras ver actuar a Nijinski, el poeta se propuso esbozar un ballet para la compañía. Remito al lector a un magnífico trabajo sobre las actuaciones de los Ballets Russes en España: Ivan Nommick y Antonio Álvarez Cañibano (eds.), Los Ballets Russes de Diaghilev en España, Granada/Madrid, Archivo Manuel de Falla/Centro de Documentación de Música y Danza/Instituto Aragonés de Empleo, 2000. 
define el legado literario de Bergamín como "complejo y polifacético, de sorprendentes 'ideas liebres' y estilo personalísimo, voluntariamente paradójico y lúdico, ajeno a los modos y modas al uso". ${ }^{3}$

Una vez terminado su libreto, el autor intentó convencer a Falla para que compusiera la música. A juzgar por lo que le dice en una carta - presumiblemente fechada hacia finales de 1926 - en el momento de escribir la obra tenía ya en mente a los artistas con que sería posible llevarla a escena. ${ }^{4}$ Pero a Falla no pareció interesarle su proyecto. ${ }^{5}$ Esto no significa que le fuera ajeno el trabajo de los jóvenes o que se cerrase a lo nuevo. Todo lo contrario. Para esas fechas estaba consciente de su jerarquía en la música española y de cierta responsabilidad de ejercer su magisterio, aunque a la postre resultase más moral y teórico que práctico. ${ }^{6}$ Muchos autores han abundado en la relación de Falla con artistas y escritores de distintas generaciones. Conviene recordar aquí su amistad con poetas como Gerardo Diego o Emilio Prados, pero especialmente con

3. Cito a lo largo de este texto diversos trabajos críticos de Nigel Dennis, cuyos aportes al conocimiento y la difusión de la obra de Bergamín resultan bien conocidos en el ámbito literario. Es preciso advertir que una parte sustancial de la información sobre el origen, el propósito y el destino de la obra literaria y la colaboración final de Halffter como autor de la música proviene de la edición del manuscrito de Don Lindo de Almería de Bergamín, preparada por este especialista. A dicho texto, que permaneció inédito más de sesenta años, se suman otros documentos relativos a la obra y a su primera representación mexicana, así como el documentado prólogo "Historia de Don Lindo de Almería" del mismo editor. José Bergamín, Don Lindo de Almería (1926), Nigel Dennis (ed. y pról.), Valencia, Pre-Textos (Letras Hispánicas), 1988.

4. Dennis, op. cit., pp. I7 y ss.

5. Falla no alude al libreto en ninguna de sus cartas a Bergamín, aunque Dennis no descarta la posibilidad de que hubiesen hablado sobre ello en uno de sus encuentros.

6. Varios autores han abordado diversos aspectos del magisterio directo e indirecto de Falla en los músicos españoles y particularmente en los de la Generación del 27. Véanse, entre otros, los siguientes textos: Emilio Casares Rodicio, "Manuel de Falla y los músicos de la Generación del 27", en Manuel de Falla tra la Spagna e l'Europa. Atti del Convengo Internazionale di Studi, Venecia (del I5 al I7 de mayo de 1987), Florencia, Leo S. Olschki, 1989, pp. 49-63; Ivan Nommick, "Manuel de Falla y la pedagogía de la composición: el influjo de su enseñanza sobre el Grupo de los Ocho de Madrid”, en Javier Suárez Pajares (ed.), Música española entre dos guerras, I9I4-1945, Granada, Publicaciones del Archivo Manuel de Falla (Estudios, Serie Música, 4), 2002, pp. 4I-70, y Ángel Medina, "Manuel de Falla: silencios, herencias, lastres y homenajes”, en Julio Andrade Malde et al. (eds.), Manuel de Falla a través de su música (I876-1946), La Coruña, Fundación Pedro Barrié de la Maza, 1996. Yo misma he abordado ciertos aspectos del magisterio de Falla sobre Ernesto Halffter en mi artículo "Devociones ejemplares: algunas pautas en la relación de Manuel de Falla y Ernesto Halffter", Cuadernos de Música Iberoamericana, vol. II, segunda época, Madrid, Instituto Complutense de Ciencias Musicales, 2006, pp. 17-50. 
Federico García Lorca, a quien conoció en 1920 cuando el compositor trasladó su residencia de Madrid a Granada. Como bien se sabe, la música era para el poeta una segunda vocación, y eso debió de ser un factor decisivo para que ambos, sin reparar en diferencias de edad o temperamento, colaborasen en proyectos como el Concurso de Cante Jondo (Granada, I922) o en la creación de la malograda ópera Lola la comedianta.

Al parecer, la experiencia de los Ballets Russes había animado a Lorca, en complicidad con Salazar, a preparar para Diaghilev el bosquejo de un ballet cuyos protagonistas serían unos títeres folklóricos andaluces (cristobitas). ${ }^{7}$ En carta del I3 de agosto de I92I, Salazar, que por entonces se disponía a publicar sus primeras composiciones musicales, diría al joven poeta que se hallaba "a tope" de trabajo y que eso mismo lo ponía "en una gran tensión de ánimo" para cuando recibiera el esperado libreto. ${ }^{8} \mathrm{El}$ mismo Salazar le aconsejaba tener en mente la posible intervención coreográfica de los Ballets Russes:

A ver si descubres nuevas cosas para los Cristobitas. La escena del zapaterillo resultará deliciosa y no debe faltar otra de un barberillo que afeita ante su puerta a Cristobitas. ¡Cómo haría esto Massin [sic]!? Consigue de todo punto necesario —insiste el crítico- el hacer dos versiones; una de ellas de ballet solo. Si consiguiéramos interesar a los rusos sería estupendísimo. ${ }^{10}$

También Falla, a quien atrajo el género en El retablo de maese Pedro, respaldó su idea de crear a la postre los frustrados Títeres de Cachiporra. En realidad, Lola la comedianta, detonante para crear otras obras en la línea en que se inscribe Don Lindo de Almería, estaba destinada a dicho teatro. Falla dejó algunos apuntes y señaló las situaciones musicales convenientes para la comicidad

7. Según se les conoce en Andalucía.

8. Refiere Lorca en su correspondencia que pensaba interesar en ese proyecto a músicos "amigos"; no sólo menciona a Salazar, sino también a otros posibles colaboradores como Ernesto Halffter, hermano de Rodolfo, y el catalán Robert Gerhard. La obra, sin embargo, se vería frustrada como tantos proyectos lorquianos. Todas esas cartas y las interesantes anotaciones que las acompañan han sido recogidas por Andrew A. Anderson y Christopher Maurer en Federico García Lorca. Epistolario completo, Madrid, Cátedra, 1997.

9. Léonide Massine (I896-1979). Entre I9I5 y I92 I fue el coreógrafo principal de los Ballets Russes y más tarde sucesor de Nijinski en la misma compañía.

ı. Carta de Salazar a Lorca. Fundación Federico García Lorca, recogida en Consuelo Carredano, Epistolario de Adolfo Salazar (I9I2-1958), Madrid, Residencia de Estudiantes/Fundación Scherzo/Centro Nacional de Investigación e Información Musical Carlos Chávez, 2008. 
de los personajes lorquianos. Durante los veranos de 1923 y i924, de acuerdo con sus indicaciones directas, el poeta hizo arreglos y adaptaciones al libreto. Aun así, el proyecto se atascó. Lorca intentó, sin éxito, reanimarlo en años sucesivos. Todo resultó inútil. Hacia mediados de la década, Falla componía cada vez menos e invertía demasiado tiempo en la preparación de obras nuevas. ${ }^{\text {II }}$ Es probable, dicen sus críticos, que esa lentitud acabara por desesperar al inquieto Lorca y que a la larga éste decidiera abandonar el proyecto.

Esto nos da una idea de lo complicado que debió resultarle a Bergamín buscar la colaboración de Falla. Y el escritor no tuvo más suerte que su amigo Federico. Cuando le hacía llegar al músico el manuscrito de Don Lindo de Almería (suponemos que esto ocurría a finales de 1926), su salud se había deteriorado. Alejado del teatro cómico que requería el libreto, se encontraba sumergido ya en la composición de la colosal Atlántida, que acabaría por agotarlo para el resto de sus días. Por lo demás, es bien conocida la decisión tomada por el compositor en esos años de no aceptar proyectos que lo desviaran de su trabajo esencial, aun cuando insistieran sus innumerables amigos o protegidos. $\mathrm{Su}$ proverbial religiosidad y sus cada vez más empecinados reparos éticos y morales debieron también incidir en forma negativa. Dennis piensa que algo en la obra de Bergamín debió lastimar la sensibilidad del compositor (quizá la "aparente frivolidad" de don Lindo o las atrevidas mulatas desnudas que aparecían en escena). Y es que, como bien hace ver el mismo autor, "por muy graciosa que fuera la picante ironía de Bergamín, en 1926-1927 dejaba de encajar en el marco moral de los intereses y prioridades de Falla". ${ }^{\text {I2 }}$

Sin duda, el primero en lamentarlo fue el escritor. A pesar de su extrañeza, la obra recogía una visión renovada del arte andaluz que el autor recogía a su vez de la experiencia de Falla, Juan Ramón Jiménez, Picasso..., es decir, el anhelo de perfección formal a través de la "depuración" o la casi "desrealización artística", para decirlo en sus términos. ${ }^{\mathrm{I} 3}$ Ese andalucismo universal, añadía Bergamín,

II. Aunque bien es cierto, como hace ver Dennis, que cuando aceptó colaborar con Lorca en Lola la comedianta ya trabajaba en la composición de El retablo (después se enfrascaría en Psyché $y$ en el Concerto).

I2. Dennis, op. cit., p. 43.

13. Ibidem, pp. 23 y ss. Aquel proceso de "depuración", al que aluden recurrentemente artistas y escritores de la etapa, será un elemento clave del arte "deshumanizado", concepto desarrollado ampliamente por Ortega y Gasset en La deshumanización del arte. La influencia del texto, publicado en I925, se hizo sentir en la configuración estética de los nuevos creadores, como se hace evidente, 
ha influido tanto en poetas, músicos o pintores nuevos — andaluces o no- que es fácil reconocer su huella en cualquier caso, y de todos es muy reconocida la trinidad andaluza a que me refiero, y aceptada, en su plena significación ideal, como la única herencia positiva, quizás, del pasado español más reciente. ${ }^{I 4}$

A la vista de sus comentarios resulta fácil entender por qué Bergamín no alcanzaba a imaginar su "pretexto figurativo", "cromoterapia costumbrista" o "juego escénico", como indistintamente denominaba a la obra, sin la música del maestro gaditano y sin los decorados del futuro autor de Guernica. ${ }^{\text {Is }}$

\section{Hacia una partitura para Don Lindo}

Según parece, el mismo Falla le aconsejó dar su libreto a Rodolfo Halffter para que compusiera la música. Al menos eso se deduce de los comentarios del escritor con motivo del estreno mexicano de la obra en febrero de 1940. Bergamín recordaba entonces haberle entregado al compositor andaluz su libreto para que éste, "o quien él mismo indicara", se encargase de ponerlo en música. ${ }^{16}$ En este punto es preciso referirse a la relación que mantenía Falla con Ernesto y Rodolfo Halffter, ya que este último nunca estuvo tan cerca del maestro como su hermano menor, a quien se ha reconocido como su discípulo por antonomasia. Si bien los hermanos iniciaron juntos su carrera de compositores (se recordará su presentación en I922, cuando se tocaron sus primeras obras para piano), diversas circunstancias provocaron que la proyección musical de Rodolfo fuera menor que la de Ernesto y que su carrera despegara varios años más tarde que la de éste.

Desde el primer momento la balanza de Adolfo Salazar se había inclinado del lado de Ernesto; él mismo se encargó de presentarlo a Manuel de Falla y de hacerle ver sus dotes estupendas. A partir de entonces, el compositor siguió y cuidó — hasta en mínimos detalles_ la trayectoria profesional y personal de quien

entre muchos ejemplos, en la obra de Bergamín o en las ideas que por entonces manifestaban el mismo Halffter y los miembros de su generación, a las que nos referiremos más adelante.

I4. Ibidem, p. 25.

15. Así lo confesaba a Falla en la carta antes citada.

I6. Según refiere Armando de Maria y Campos ("El ritmo del teatro", Hoy, núm. 156, I7 de febrero de 1940). Incluido en la citada edición de Don Lindo de Almería de Dennis, p. Ior. 
sería su más devoto pupilo. ${ }^{17}$ Esa proximidad con Falla también actuó a favor de Rodolfo. La abundante correspondencia entre Ernesto y el maestro gaditano nos lo confirma. A finales de 1926, Ernesto aludía a las correcciones que Falla hizo a uno de los primeros trabajos orquestales de Rodolfo. Resultan emotivas las palabras del más joven al agradecerle el tiempo precioso que dedicaba a su hermano y el enorme provecho que suponía para éste el contacto directo con el compositor:

Muy de corazón le agradezco todo su interés por Rodolfo, que está ilusionadísimo desde sus conversaciones con ud. y ahora trabaja mucho y contento; está terminando una Suite para la Bética que quisiera estrenar en esta tournée; ahora comprenderá ud. el efecto que hacen sus palabras. ${ }^{18}$

A pesar del éxito obtenido en esa presentación juvenil (Adolfo Salazar se encargó de destacarlo en su crítica al concierto), ${ }^{19}$ el padre, un próspero joyero de origen prusiano, quiso desalentar las intenciones musicales de sus hijos. Por lo que respecta a Ernesto, sólo la actitud tesonera de Salazar - y a petición de éste, la oportuna intervención de Falla—, le permitiría consagrarse por entero a su vocación. Para allanarle el camino, el autor de El amor brujo le gestionó un trabajo que habría envidiado cualquier músico de su edad e incluso mayor. Sin cumplir los 20 años, y con unas cuantas lecciones proporcionadas por el mismo Falla en su casa de Granada, lo nombró director de la Orquesta Bética de Cámara de Sevilla. Ese novedoso proyecto daría a Ernesto la oportunidad de proyectarse nacional e internacionalmente como director y compositor. El solo nombre de Falla debió ser, sin duda, una buena carta de presentación para él. Pero los premios no llegan sólo por los buenos contactos. En un momento dado - es una estimación generalizada-, las enseñanzas de Falla parecieron cristalizar en la figura de los Halffter: el mismo año en que debutaba como director de la Bética, recibió la beca de la Junta Nacional para Ampliación de Estudios y un año después, por primera ocasión en

17. Como se sabe, los únicos miembros del Grupo de los Ocho propiamente discípulos de Falla fueron Rosa García Ascot y Ernesto Halffter. Ivan Nommick añade además el nombre del compositor argentino Juan José Castro.

I8. Véase la carta de Ernesto Halffter a Falla, 24 de noviembre de 1926 (Archivo Manuel de Falla, Granada).

19. Adolfo Salazar, "El intimismo húngaro. Dos jóvenes músicos alemanes. F. Ember”, El Sol, 29 de marzo de 1922. 
su vida, el Premio Nacional de Música, máximo reconocimiento al que podía aspirar un músico español.

Rodolfo tuvo una juventud muy distinta. Su condición de primogénito lo obligó a enfrentar los reveses económicos familiares y a emplearse como contable en un banco. Después — según confesó más tarde en una entrevista- se vería forzado a dejar la música por un tiempo. ${ }^{20}$ En otras palabras: mientras Ernesto recibía estímulos, becas y mecenazgos importantes - lo cual le permitió establecerse largamente en París, estrenar algunas obras, obtener ciertos encargos y un contrato con el editor francés Max Eschig-, Rodolfo no contaba sino con los eventuales consejos de Falla y el aliento de una vocación que, cabe suponer, debió sufrir altibajos. Como consecuencia de todo esto, su carrera se rezagó.

El hecho de que la suite del ballet Don Lindo de Almería se estrenara en España diez años después de que Sinfonietta, de su hermano, se consagrara como la obra por excelencia de la nueva generación no le resta méritos ni rebaja la importancia de la pieza que nos ocupa. Por lo demás, se ha desestimado hasta ahora el menoscabo vocacional e incluso moral que pudo provocar en Rodolfo Halffter aquella inesperada responsabilidad familiar, mientras atestiguaba, por otro lado, el sonado éxito de su hermano menor. Si con su habitual discreción Falla cuidaba de no airear su inclinación por Ernesto, Salazar no escatimaba elogios y comparaciones. Su actitud resultaría aplastante para uno e incómoda para el otro. Los insistentes mimos del crítico incluso llegaron a irritar al halagado compositor — por no hablar de muchos otros colegas suyos que se sintieron desplazados. Años después, en un pasaje por demás difundido de su biografía, al reflexionar sobre la apuesta estética de sus compañeros de grupo, Rodolfo Halffter insinuaba esa actitud "exclusivista" de Salazar hacia su hermano: "En Madrid, faltó la figura que — como Erik Satie en París - fortaleciera los vínculos que nos ligaban”. Salazar, ese "ladino y astuto" crítico musical, "pudo ser, en determinado momento, el punto de convergencia de nuestros anhelos, la masilla aglutinante; pero sus vaivenes en el terreno de la estética, sus campañas periodísticas y su exclusivismo frenético nos apartaron pronto de él". ${ }^{21}$

20. Citado por Iglesias en op. cit., p. I5.

2I. Rodolfo Halffter, "Julián Bautista”, en Emilio Casares (ed.), La música..., op. cit., pp. 89-93. Sin duda este tema requeriría una reflexión más profunda que excedería los límites y propósitos de este ensayo. 
No conviene insistir en detalles sobre la conformación del llamado Grupo de los Ocho o Grupo de Madrid. ${ }^{22}$ Sin embargo, es importante recordar que su presentación oficial en los primeros tiempos de la segunda República tuvo lugar en la Residencia de Estudiantes, el importante centro cultural madrileño. ${ }^{23}$ Ramón Gómez de la Serna evocó entusiasmado aquella aparición. Sensible a las escasas oportunidades que parecían tener algunos para difundir sus trabajos, anotaba contundente: “Todo parecía cerrado a una nueva generación de músicos: pero en reserva, como recibiendo un mandato hereditario inalienable, la nueva generación estaba próxima a su eclosión como tal generación compacta, formada en número suficiente, el 8 por casualidad". ${ }^{24}$

No es difícil suponer que la relación entre nuestro compositor y Bergamín fructificara en el mismo entorno de la Residencia. Rodolfo Halffter consideraba al escritor un vocero de su grupo. Por eso no sorprende que se implicara en la aventura e hiciera suyo el término cromoterapia, acuñado por Bergamín para definir la estética de la obra. Sus comentarios lo ratifican:

Uno de nuestros portavoces, el agudo escritor José Bergamín, puso en circulación el neologismo "cromoterapia". Y nosotros creíamos, de buena fe, haber descubierto fórmulas terapéuticas adecuadas para el tratamiento del "colorismo" convencional de nuestra música popular, el cual, considerábamos, es con frecuencia una degeneración del casticismo. ${ }^{25}$

Como ya indicábamos, nuestros autores empezaban sus carreras en años en que se imponían nuevas tendencias en el arte, de acuerdo con la lección estética de Ortega y Gasset; conceptos entonces vigentes, como la ironía y el humor, definían el carácter de muchas obras del periodo. Según diría Rodolfo Halffter, él y

22. Rodolfo y Ernesto Halffter, Rosa García Ascot, Salvador Bacarisse, Julián Bautista, Juan José Mantecón, Gustavo Pittaluga y Fernando Remacha. Aceptamos esta denominación porque resulta más precisa que las de Generación musical del 27 o Generación de la República, etiquetas que de un tiempo a esta parte han sido revisadas en diversos trabajos. Véanse, por ejemplo, Javier Suárez Pajares, "Introducción. El periodo de entreguerras como ámbito de estudio", y Emilio Casares Rodicio, "La Generación del 27 revisitada", en Suárez Pajares (ed.), Música española..., op. cit., pp. 9-17, $2 \mathrm{I}-37$.

23. Subrayamos esto, pues, como hacen ver distintos autores, por su cuenta todos habían empezado a producir obras desde los ańos de la dictadura de Primo de Rivera (I924-I93I).

24. Ramón Gómez de la Serna, "Horario. Los ocho en pie y en fila", El Sol, 7 de diciembre de 1930. Recogido por Dennis en su edición de Don Lindo de Almería, op. cit., pp. 46-47.

25. Halffter, "Manuel de Falla...", en Ruiz Ortiz, op. cit., p. 53. 
sus compañeros de generación aspiraban a escribir una música pura, "purgada del folklore de pandereta, de la contaminación literaria o filosófica, de la exhibición de sentimientos primarios" ${ }^{26}$ Esto supuso un punto de encuentro con los poetas del 27 y se manifestó de diversas formas, como ha sido justamente destacado. Las palabras de Gómez de la Serna: “¡Ya tenemos hermanos declarados en el otro arte!”, resultan por demás elocuentes.

Tal coalición se observa también en abundantes colaboraciones surgidas especialmente en esos ámbitos, tanto en el plano de la creación artística original como en el de proyectos de difusión. Antes se indicaron los planes de asociación entre Lorca y Salazar, Ernesto Halffter o Robert Gerhard. En distintos trabajos se ha registrado la participación de los mismos Ernesto y Rodolfo Halffter y de Gustavo Durán con Rafael Alberti para poner música a algunos poemas de Marinero en tierra; bastaría recordar las dobles vocaciones literario-musicales del mismo Lorca, Gerardo Diego y Jesús Bal y Gay. El testimonio de algunos ex "residentes" coincide al afirmar que la música "vivió y fue vivida" en la Residencia de todos los modos posibles. ${ }^{27}$

En esta misma sintonía de intercambios interesa subrayar un hecho: García Lorca leyó el libreto de Bergamín porque éste se lo pidió. Y seguramente le agradó, a juzgar por lo que el autor le responde en febrero de I927: "Que te haya gustado y divertido mi Don Lindo casi me conmueve" —le dice Bergamín. En esas fechas, el granadino estaba hondamente interesado por la música. ${ }^{28}$ Quizá por eso le ofreció consejos en tal sentido. Aunque no conocemos las palabras exactas del poeta, las intuimos a partir de lo que le responde Berga-

\section{Ibidem, p. 43.}

27. En su artículo "La música en la Residencia de Estudiantes", Jorge de Persia cita entre otros testimonios el de Bal (en Casares [ed.], La música..., op. cit., p. 49). Pero habría otros ejemplos. En junio de I93 I sobresale una representación de la Historia del soldado en la Residencia de Estudiantes, lo cual supuso su estreno en Espańa y la celebración del 50 aniversario de Stravinski. En la obra, traducida por Luis Cernuda, se conjugó el trabajo de Ernesto Halffter como director del pequeño grupo instrumental, de Cipriano de Rivas Cherif en la dirección de escena y del pintor Daniel Vázquez Díaz como realizador de los sencillos decorados. Resulta por demás interesante la sustanciosa crítica de Salazar para aquel acontecimiento: "Strawinsky y la Historia del soldado", El Sol ("La vida musical"), I3 de junio de I93I.

28. Como bien se sabe, durante algún tiempo Lorca tomó muy en serio sus estudios musicales y se interesó por las expresiones musicales populares. En el verano de I92I, cuenta a Salazar que está estudiando guitarra y que ya acompaña "fandangos, peteneras y er cante de los gitanos, tarantas, bulerías y ramonas". Carta de García Lorca a Salazar, Fundación Federico García Lorca, recogida en Carredano, Epistolario..., op. cit., p. I I4. 
mín: “¿La música? Es verdad: dorada y vacía como una nuez, y habanera, naturalmente; y golpes de timbal. Todo lo has visto claro. Exacto". Lorca encuentra en todo el ballet "un delicioso aire colonial de litoral gaditano"; de ahí que considerase más apropiado que Bergamín cambiara su título por el de "Don Lindo de Cádiz":

Es necesario recordar irónicamente el ritmo de la habanera para comprenderlo. Almería tiene una aspereza y un polvo azafranado de Argel que no sienta bien con los rasgos de sainete último que también has dibujado. Cádiz, en cambio, puede agrandar sus papagayos y palmas hasta donde diga "basta" el siglo xvir. La plasticidad del ballet es magnífica. Pero lo que la música necesita, a mi juicio, es una música sin meollo. Una música exterior, como una nuez dorada y vacía. ${ }^{29}$

Estas coincidencias entre músicos y escritores se refrendan, además, al reflexionar sobre la actitud que muchos de ellos adoptaban frente a lo popular. Falla indicó un camino: la aproximación intelectual e irónica al cante popular; extraer su esencia e incorporarla a la creación propia. Entre otras cosas, en eso consistía la llamada "renovación del lenguaje". Gracias a la producción de Falla —explicaba Rodolfo Halffter-, "nuestro Grupo" hizo hallazgos fundamentales. Los ballets Corrida de feria de Bacarisse, La Maja de Remacha y Juerga de Bautista, la zarzuela El loro de Gustavo Pittaluga y su propio Don Lindo de Almería así lo comprueban. ${ }^{30}$

El término "cromoterapia", acuñado por Bergamín para su obra, determina, en rigor, la estética seguida por Halffter. En su declaración de intenciones él mismo lo definía como un antídoto al andalucismo barato que abría paso a visiones más profundas y sugerentes de Andalucía, en las que además el factor humorístico servía también como vía de escape de cualquier pretensión nacionalista.

Por lo que hablan las propias fuentes y lo que él mismo escribió, Bergamín quedó plenamente satisfecho con el resultado musical (después de la represen-

29. Citado en Dennis, op. cit., pp. 20-22.

30. Para sus contemporáneos y, en general, para los músicos del entorno de Falla, el Cancionero popular de Pedrell constituía — es siempre Halffter quien habla — una especie de libro de horas: "Dalí, por ejemplo, solía decir, con marcado acento catalán, a sus compañeros de la Residencia de Estudiantes: 'Cuando Federico agarra el diccionario ( sic) de Pedrell, se pone insoportable; pero eso sí, con su voz y su piano nos descubre una multitud de joyas de belleza incomparable". Halffter, "Manuel de Falla...", en Ruiz Ortiz, op. cit., p. 49. 
tación de Don Lindo en México ambos se enfrascaron en un nuevo proyecto). ${ }^{31}$ Para Juan Rejano, la propuesta de Bergamín inauguraba una fórmula en que la inclusión de tipos, ambientes y situaciones "no procede por acumulación sino por desintegración; no por revelaciones sino por abstracciones". ${ }^{32} \mathrm{Hal}-$ ffter consiguió reflejar en su partitura una fórmula similar al poner en juego las mismas estrategias narrativas de fragmentación. Esto se traduce en la dinámica sucesión de temas breves, motivos y giros melódicos extraídos de líneas que se adivinan más amplias y que, aun en su descomposición —o tal vez por eso- - preservan una gracia natural que no altera la concepción austera de la obra. En otras palabras, Halffter se propone desarticular cualquier ilustración musical concreta y descontextualizar los trazos que definen una época o estilo musical específicos.

La parquedad de materiales sonoros y recursos compositivos - una enseñanza proveniente de Falla, y que será una cualidad en futuras obras de Halffter- confirma, por un lado, las exigencias técnicas de su autor; por otro, la vocación "clásica" de una partitura que no renuncia, sin embargo, a su vocación contemporánea. No sería difícil conectar esta idea con otro referente literario profusamente cultivado en la época como es el aforismo: forma breve, fugaz, fragmentaria y discontinua: "No se piensa más que en aforismos", decía Unamuno en una frase que el propio Bergamín solía citar. ${ }^{33}$

Algunas constantes que encuentra Dennis en la suma poética del autor del libreto ayudan también a comprender el contexto estético en que Halffter desarrolla su trabajo. El crítico se refiere a la delicada alternancia de la copla sencilla y evanescente de raíz popular, al denso soneto metafísico, de procedencia barroca y conceptista, y a la esporádica aparición de poemas satíricos y burlescos dedicados circunstancialmente a "las cosas que pasan" (o que "no pasan", como decía el poeta). ${ }^{34}$ En Don Lindo de Almería, la anécdota y los personajes se reducen a un sencillo esquema de evocación. De ahí ese desfile de objetos, presencias y símbolos aparentemente incoherentes que Halffter entendía así:

Reducidos a jeroglíficos, en rápida sucesión de escenas, desfilan muchos personajes del diario acontecer andaluz del presente siglo: la beata, como el cuervo, de luto

3I. El ballet La madrugada del panadero (1940).

32. Citado por Dennis.

33. José Bergamín, Obra esencial, Nigel Dennis (pról. y comp.), Madrid, Turner, 2005, p. 17.

34. Ibidem, p. Iо. 
perenne, la mocita de talle de nardo, con un clavel siempre prendido en el cabello; la inevitable pareja de la guardia civil; los tres curas de la buena suerte; el intercesor San Antonio, que suele apiadarse de las jovencitas sin novio; el torerillo que, según la copla, aparece bordado en los pańuelos, rodeado, como el famoso matador Reverte, por cuatro picadores; las mulatas con sus vistosas batas de volantes; la cacatúa, heredera del imperio ultramarino hispánico, diluido éste en ritmos de guajira y habanera, en melodías teñidas de languidez y melancolía o llenas de coquetería y voluptuosidad. Y, por último, el protagonista: Don Lindo, viejo y noble caballero, enjuto y de tez aceitunada. Se presenta en escena, caído del cielo y enviado por San Antonio, para casarse con la mocita. Para luego descasarse de ella, cuando el torerillo surge en el ruedo pasional de la esposa casquivana. Con el corazón hecho añicos, Don Lindo, para quien vivir es necesidad de olvidar, regresa a los cielos, lugar apropiado para resucitar el recuerdo, sobre el cerdito que cabalga, atravesado éste por el fatal estoque del torero, y que le trae a la memoria su San Andrés hogareño. "Por San Andrés, reza el refrán, quien no mata a un cochino, mata a su mujer." 35

La finalidad de Halffter, explicada en sus términos, consistía en "abstraer y aquilatar la verdadera naturaleza de lo popular, de desintegrar el cromo", exagerándolo "hasta el extremo de presentar un juego, aparentemente incongruente, de simples referencias a figuras, gestos, hábitos y despojos de cantares". El argumento "apenas y sirve a la música sino como hilo conductor", como "pretexto" - diría el compositor- "sobre el cual bordar una serie de alusiones a proverbios, usos y costumbres de la vieja Andalucía". ${ }^{36}$

Rodolfo Halffter — según Rejano- sale airoso del reto planteado por Bergamín, el cual consiste en llenar un desfile de "huecos esenciales". Su música se aleja de los dos extremos más peligrosos del caso:

la comodidad folklorista y el barroquismo ornamental. Con una desnudez absoluta en los conceptos y en las ideas, Rodolfo Halffter ha construido una música que, si en su escritura es de una limpidez y una depuración extremadas, en su expresión condensa, dentro de un lenguaje terso, con acentos universales, el aire de la espańolidad. ${ }^{37}$

35. Rodolfo Halffter, "Borrador para un programa de mano", México, Archivo de Ediciones Mexicanas de Música, s.f.

36. Idem.

37. Juan Rejano, "Don Lindo de Almería en el cielo de México", en Ruiz Ortiz, op. cit., p. 190 . 


\section{La recepción de la obra}

No hemos podido establecer la fecha precisa en que Rodolfo Halffter inició la composición de Don Lindo de Almería. Aunque aseguraba que Bergamín le había mostrado el libreto a finales de 1934, el dato resulta poco probable; en ese caso, deberíamos concluir que la realización le habría tomado sólo unos cuantos meses. El crítico español Antonio Iglesias, estudioso de su obra para piano, nos recuerda el pausado ritmo de trabajo de Rodolfo Halffter y el hecho de que no tuviera "una excesiva prisa por dar a conocer sus pentagramas". Creemos, en cambio, que desde 1929 el proyecto pudo haber empezado a cobrar forma; el testimonio de Jesús Bal y Gay refuerza la idea. En una crítica al estreno del ballet en México, su también colega en el exilio diría que alrededor de 1930 la obra se encontraba en proceso; recordaba haber escuchado algunos pasajes de ella en el piano de la Residencia de Estudiantes. ${ }^{38}$ Que se sepa, el compositor no contravino en su día los comentarios de Bal; tampoco éste rectificó sus anotaciones en críticas posteriores, como pudo hacerlo en caso de requerirse.

El hecho de consignar en su "cronología" una estancia en Granada para "revisar" con Falla algunas obras nos llevaría a suponer que ya entonces hubiesen discutido el proyecto. En la citada carta de Rodolfo Halffter a Falla (mayo de 1928) le hablaba convencido de El retablo como modelo a seguir. Este dato conviene tenerlo presente, como también el hecho de que hubiese pasado en I934 una temporada en París para componer la música de La traviesa moline$r a$, según consta en dicha cronología. Cabe suponer que su primera incursión cinematográfica debió consumirle a Rodolfo Halffter varios meses del año, dejándole poco tiempo libre para otras tareas creativas.

Sea como fuere, el I3 de marzo de 1936 Pittaluga realizó el estreno absoluto de la versión orquestal de la obra en el Collège d'Espagne de la Ciudad Universitaria de París. Un par de semanas más tarde se tocó en Barcelona y en Madrid. Como indicábamos al inicio de este trabajo, Don Lindo fue elegida por el jurado de la Sociedad Internacional de Música Contemporánea para uno de los conciertos del festival, ese año celebrado en la ciudad Condal. ${ }^{39}$ En el programa ofrecido por Bartolomé Pérez Casas y la Orquesta Filarmónica de Madrid (23 de abril) en el Palau de la Música Catalana, se anunciaba como un

38. Jesús Bal y Gay, “Un ballet creado en México”, El Universal, i4 de enero de I940.

39. Junto a otras obras de Federico Elizalde (discípulo de su hermano Ernesto) y de los catalanes Robert Gerhard y Manuel Blancafort. 
"divertimento coreográfico"; no obstante, su presentación carecía por completo de la situación dancística. ${ }^{40}$ Salazar calificó la obra como lo más perfecto que hubiera salido de la pluma de Rodolfo Halffter: "Habida cuenta de que la perfección y minuciosidad en la escritura es uno de los aims, de los puntos de mira que este Halffter, como su hermano, tiene constantemente a la vista" ${ }^{41}$ En medio de lo que le pareció a Salazar un programa compuesto por "atrocidades de varias índoles", la suite de Don Lindo de Almería sonó — diría - como "un lirio entre cardos" e "infinitamente más atractiva que los bodrios ultracromáticos y ultramontanos, tan en boga en el centro de Europa". ${ }^{42}$ Destacaba la formidable hazaña de Rodolfo Halffter frente a una propuesta literaria de tal dimensión, por cuanto se vio precisado a seguir la estética de Bergamín. No dejaba de reconocer Salazar, sin embargo, que Halffter había dado un paso adelante en su oficio y aludía a la "gran seguridad de mano tanto en la confección del estilo como en el corte de la forma [... y y en el equilibrio de la orquesta".

Pero más adelante percibimos en sus comentarios cierta falta de objetividad, como si denunciara en Rodolfo Halffter su tardía conversión al neoclasicismo. No dejaba de parecerle osado que de pronto se propusiera crear una obra de estas características:

Digo que se lo propone, porque no puedo asegurar que el propósito esté enteramente logrado, aunque sí en muy buenas vías. Es éste un propósito sutil que exige un largo trabajo de preparación, y no es fácil conseguirlo de buenas a primeras, aunque el temperamento minucioso, el gusto por la pincelada pequeńa y por las formas diminutas, que es propio de Rodolfo Halffter, le haga especialmente propicio a tales fines. Por lo pronto lo que este Halffter hace es desfigurar ligeramente las frases, como desecándolas de su pringue pintoresca. Guajiras, sevillanas, pasodobles

40. Según apunta Dennis, Don Lindo se presentaba con obras del estadounidense Carl Ruggles, del suizo Frank Martin, del rumano Marcel Mihalovici y del polaco Roman Palester.

4I. "La XIV reunión de la simc en Barcelona - Los conciertos. Orquesta Filarmónica. Rodolfo Halffter", El Sol, "La vida musical", Madrid, 3 de mayo de 1936. Salazar dedicó a los festivales una serie de ocho artículos en El Soly en los tres últimos hace comentarios a las obras españolas incluidas en los programas.

42. Al respecto, ańadiríamos que la mayor parte de las obras incluidas en los programas de la simc le parecían vanguardistas en extremo o insoportablemente ampulosas. Aunque Salazar pasaba como el más modernista entre los críticos, sus preferencias no se orientaban hacia el posromanticismo centroeuropeo, el serialismo o las obras especulativas; más de una vez se encargó de aclarar lo anterior a quienes se empeńaban en considerarlo amante de todos los modernismos por el simple hecho de serlo. 
y demás "atrezzo" del nacionalismo andalucista aparece machacado en el mortero del laboratorio, mezclado secundum artem y reducido a pequeńas pastillas. Espíritus volátiles de una música sometida a un proceso de destilación que, como resultado definitivo, es gracioso, fino, posee una neta cualidad musical, un poco seca, con un olor un tanto farmacéutico, como corresponde.

Tampoco pasa por alto el que su música estuviese todavía estrechamente ajustada al modelo de Falla, en lo que respecta a giros motívicos, a su tratamiento y a ciertos rasgos armónicos e instrumentales. Las obras anteriores de Rodolfo Halffter, como él mismo lo haría ver más tarde, pertenecían a tendencias muy distintas a las que siguió en Don Lindo de Almería. Para reconocerlo no habría más que evocar los sesgos cromáticos y atonales de su Naturaleza muerta (1922).

En síntesis: Salazar no veía en Don Lindo un ballet sino "música de escena". "El ballet — decía — obliga, en rigor, a formas conclusas, más cerradas y redondas”. ¿Debemos interpretar que musicalmente la obra no le pareció a Salazar una entidad redonda y cerrada en sí misma? En cualquier caso, habría que considerar que la versión escuchada por él en abril de 1936 bien pudo no ser la definitiva. Es probable, siguiendo su costumbre, que en México retocase la partitura después de representada la obra e incluso antes de darla a la imprenta en 1957. Nada sabemos, sin embargo, por el mismo Halffter, que habló poco de los procesos de composición y revisión de sus obras. Tampoco hemos podido confirmar su presencia en el concierto de Barcelona, aunque sabemos que Salazar pidió a Ernesto Halffter delegar en su hermano la representación oficial que le correspondía como miembro del Comité de Madrid. 43

En una carta posterior, el mismo Salazar le hacía notar a Ernesto que encontraba en la obra la influencia de Falla y el carácter más bien "convencional" de ésta, tanto más cuanto que se escuchaba en un festival consagrado a lo último de la vanguardia europea: "Te enviaré el libro grande con los programas con todo lo que se ha tocado alli" - le cuenta a Ernesto. "Como de costumbre, mucho malo. La música de Rodolfo salió muy bien y produjo buen efecto, pero en general, en todos esos festivales sólo agrada la música

43. En el que Salazar se desempeñaba como secretario; este comité constituía, con el catalán, la representación española ante la Sociedad Internacional para la Música Contemporánea. Para tales fechas, Ernesto Halffter se encontraba fuera de España. 
ultracromática y atonal, y la nuestra tan modestita y tan tonalita parece un poco cosa infantil." 44

Días después, cuando el mismo Pérez Casas y su orquesta interpretan la obra en el Teatro Español de Madrid, Salazar suaviza sus comentarios: "Todos los valores [de Don Lindo...] ganan al estar presentados en un ambiente más sereno, lejos de las cosas desorbitadas e hipertróficas que componen en gran mayoría los programas de los festivales de la SIMC". En su opinión, la acústica de ese teatro "más recogido" favorecía a la obra, la orquestación le parecía "más centrada" y se percibían con mayor justeza los procesos dinámicos y la gama de claroscuros. El resultado final era, pues, "favorable para la cohesión misma de la forma". Por lo visto, el programa de mano, confeccionado con menos prisas que el de los festivales catalanes, detallaba el título de cada pasaje, obligando "al auditor a detenerse en cada cual". Cuando ese detalle no se menciona — agregaba Salazar-, "el auditor siente la propensión de entender la obra en su totalidad, como una obra redonda, cerrada de forma, lo cual la perjudica, puesto que en rigor, no es sino un mosaico". 45

$\mathrm{Al}$ año siguiente, mientras el gobierno legítimo libraba en España la defensa de la República, Don Lindo alcanzó una nueva interpretación en el marco de la "Exposición de las Artes y las Ciencias en la vida moderna" de París. Las difíciles condiciones económicas obligaron al pabellón español a limitar sus presupuestos. Aun así, el comisariado alquiló el Théâtre des Champs-Élysées y celebró un par de conciertos con obras españolas contemporáneas. ${ }^{46}$ Esto supuso, además, una de las escasas muestras de música "culta" en la reunión internacional, cuya tendencia favorecía la música folklórica. ${ }^{47}$ Los conciertos, profusamente anunciados en la prensa parisiense, contaron con la colaboración de la Société des Concerts du Conservatoire de París, de su orquesta y de los directores Roger Desormières y Bartolomé

44. Carta de Salazar a Alicia y Ernesto Halffter, Madrid, 8 de mayo de 1936, Archivo de Manuel Halffter Cámara Santos, recogida en Carredano, Epistolario..., op. cit., p. 295.

45. Salazar, "La XIV reunión de la SIMc", op. cit.

46. Los días 2 I y 22 de septiembre de 1937.

47. En la Feria Mundial, casi todos los países participantes privilegiaron la presentación de música folklórica como expresión viva de su patrimonio cultural. Como recuerda María Palacios, "En esos momentos, Europa atravesaba una grave crisis de preguerra y todos los países sufrían por estas circunstancias una revitalización del sentimiento nacional y una reafirmación de las raíces culturales propias". Véase Palacios, "La música en las exposiciones internacionales de Barcelona (I929) y París (1937)”, en Suárez Pajares, Música española..., op. cit., pp. 236 y ss. 
Pérez Casas. ${ }^{4}$ En el primer programa, Don Lindo de Almería compartió cartel con obras de Remacha, Bautista y del compositor Antonio José, mártir de la guerra civil, quien cayó en manos de los fascistas en los primeros momentos de la insurrección militar. ${ }^{49}$

Los comentarios en los diarios franceses se sujetaron a tópicos comúnmente aplicados a la música española (el pintoresquismo andaluz, la riqueza popular del folklor...) y hacían hincapié en el "lenguaje neoclásico", característico de la joven escuela española. De Don Lindo, el crítico de L'Humanité destacaba su "violencia contenida", su "buen humor barroco" y "la inspiración en el Goya de los tapices". ${ }^{\circ}$ En España apenas se habló del acontecimiento de no ser para mencionar la asistencia del embajador espańol. Es probable, aunque no seguro, que Rodolfo Halffter también estuviera presente. Por esas fechas realizaba en el pabellón español — que exponía el célebre Guernica - una misión peculiar: la sincronización al francés de la película Castillos en Castilla. ${ }^{5 \mathrm{I}}$

Antes de estallar la guerra, Halffter y Bergamín habían entablado conversaciones con Picasso y Miró para escenificar la obra. ${ }^{52}$ Pero esas gestiones se truncaron debido a los sucesos de julio de 1936, fecha en que ambos abandonaron sus propias tareas y dedicaron sus esfuerzos para luchar en favor de la República. Rodolfo Halffter se trasladó a Valencia y se hizo cargo de diversas tareas en el gobierno republicano. En los tres años que duró la guerra, la vida de ambos siguió una trayectoria similar hasta que lograron trasladarse a México con sus familias y comenzar una nueva vida. Es de suponer que, entre los manuscritos y las obras que Halffter perdió en España durante los bombardeos, no se encontraba la partitura de Don Lindo. ${ }^{53}$ Gracias a ello, poco después de su arribo, ambos artistas llevaron a feliz término su proyecto.

48. Idem. Por lo demás, al año siguiente el director y compositor francés Désiré-Émile Inghelbrecht (1880-1965) ejecutó nuevamente la obra, según hace constar el mismo Halffter en la mencionada cronología.

49. El programa estuvo compuesto por Cataluña (1899) de Albéniz, El amor brujo (1915-1916) de Falla, Liturgia negra (1926) del compositor hispano-cubano Pedro San Juan, Suite all'antica de Julián Bautista, La Maja vestida (I9I9) de Fernando Remacha y el estreno de Evocaciones de Antonio José, en versión orquestada por Julián Bautista. Palacios, op. cit., p. 244.

50. Idem.

5. Idem.

52. Según refiere Adolfo Salazar en La danza y el ballet, México, Fondo de Cultura Económica (Breviarios), 1949, p. 219.

53. Como fue el caso, entre otras, de su ópera bufa Clavileño, que nunca se decidió a reconstruir. 
Las circunstancias que rodearon el estreno del ballet-mojiganga Don Lindo de Almería, según rezaba el programa del estreno en el Teatro Fábregas el martes 9 de enero de 1940, constituyen un episodio suficientemente conocido de la vida de Halffter en el exilio, al que él mismo concedía un significado especial por cuanto suponía una tarjeta de presentación ante el público mexicano y, además, su incorporación "formal" al ambiente cultural de este país. Con la bailarina y coreógrafa estadounidense Ana Sokolov — discípula de Martha Graham, a quien conocieron poco después de su arribo-, Halffter y Bergamín iniciaron los planes para montar la obra. De aquellas gestiones - recuerda Rodolfo Halffter - partieron las iniciativas que darían lugar no sólo al establecimiento de una compañía - que en aquella ocasión se presentó con el nombre provisional de Grupo Mexicano de Danzas Clásicas y Modernas (después tomaría el poético nombre de La Paloma Azul)—, sino también al posterior florecimiento del movimiento dancístico mexicano.

Aunque ninguno de los autores ofrece un relato detallado de los embrollos económicos que debieron desafiar, siempre se habló de la generosidad de un veterano actor cómico español. El también empresario ofrecía una temporada de zarzuela en el Teatro Fábregas y se comprometió a incluir Don Lindo después de una función de La del manojo de rosas. No es difícil suponer, por las características del libreto, que la obra resultaba un tanto enigmática para los gustos conservadores de un público acostumbrado a la simplicidad típica de los argumentos de zarzuela. Tanto más cuanto que incluso hoy se reconoce la dificultad para desentrañar algunas obras de Bergamín, no sólo para el lector desprevenido sino también para el crítico profesional. Pese a todo, la representación constituyó un suceso artístico y obtuvo una acogida entusiasta de los conocedores y de los músicos presentes en la sala. Halffter recordaba entre el público la grata presencia de Carlos Chávez, Blas Galindo y Silvestre Revueltas.

La prensa especializada recogió buenos comentarios. En su columna de $E l$ Universal, Jesús Bal y Gay destacaba el "escrupuloso" cuidado con que estaba escrita la obra y ponderaba las cualidades del compositor: economía de material sonoro, desinterés por los desarrollos profusos, vocación por la música "esquemática” y "angulosa". Rodolfo Halffter no parece, "al menos hasta ahora —escribía Bal—, afecto a las formas grandes, a la técnica amplia de trazo y generosa de materia". Prefiere "un ámbito reducido y un oficio minucioso". Ello — decía— viene de perlas a intenciones como la de Don Lindo, con sus solas referencias abstractas a lo folklórico español. "Que la realización esté de 
acuerdo con los designios es el mejor elogio que puede hacerse de una obra de arte, y ése es el que merece la música de Don Lindo." 54

Tras la primera representación, no faltó, sin embargo, quien se empeñara en atribuir a la obra pretensiones de ridiculizar sentimientos de religiosidad católica. Como bien se sabe, las acometidas de la prensa conservadora eran plato cotidiano para los republicanos españoles, y la obra de Bergamín les servía en bandeja de plata una nueva oportunidad de ataque. Pero el escritor reaccionó al día siguiente. Junto a los programas de mano hizo repartir una nota conminando a los espectadores a no dejarse embaucar por cronistas de mala fe y propagandas "tendenciosas" y "políticamente interesadas". 55

\section{Observaciones sobre algunos recursos de composición empleados en la obra}

Es preciso entender Don Lindo de Almería en el contexto del neoclasicismo español inaugurado por Falla. Como apuntan los estudiosos de su obra, El retablo marcó la presencia definitiva de una vanguardia internacional en España y devino un vínculo ineludible para la nueva composición, especialmente para el Grupo de los Ocho. Rodolfo Halffter no deja dudas al respecto: "Mi intención es acercarme - aunque, claro está, no lo consiga sino a buena distancia - a El retablo y al Concerto — obras admirables que, sin duda, han de servir de fundamento a la nueva música espańola”, escribía en carta al compositor el I4 de mayo de $1928 .{ }^{56}$

En efecto, la técnica de trabajar estilizaciones a partir de músicas anteriores o materiales folclóricos prestados — desarrollada por Stravinski en los ballets Historia del soldado (1918) y Pulcinella (1920), y quizá antes en sus Piezas fáciles para piano a cuatro manos - atrajo a la sensibilidad española por conducto de Falla, tendencia estética a la que se adjudicó la etiqueta de neoclasicismo. Los vínculos entre nacionalismo y música antigua habían sido proclamados por la escuela moderna francesa; ${ }^{57}$ también en España la ruta nacionalista

54. Bal, op. cit.

55. Texto citado por Dennis, op. cit., pp. I03-I04.

56. Citada por Nommick, "Manuel de Falla...", op. cit., p. 4I.

57. Como señala Michael Christophoridis al citar a Scout Messing: "En la búsqueda de modelos alternativos [al legado de Wagner y Brahms] muchos artistas franceses fortificados por un nacionalismo cada vez más vocífero se acercaron a su pasado pre-romántico que se interpretó como una encarnación inherente en su raza". Véase Christophoridis, "De La vida breve a Atlántida: 
marcada por Pedrell sugería la incorporación de modelos españoles antiguos. En ese sentido, reflexionaba Falla, "La música novísima es pura y simplemente la renovación de aquella otra por tantos siglos olvidada". Y es precisamente esa confluencia de ambos elementos lo que habría permitido, de acuerdo con varios autores, concebir obras como El retablo o el Concerto. Así pues, las primeras manifestaciones del neoclasicismo español habrían fructificado sobre las bases teóricas de Pedrell y la asimilación del moderno ideal parisiense, cuyas influencias, como se ha reconocido, determinaron en buena medida la estética falliana.

Pero conviene tener presentes otros aspectos. En su Autobiografía (1936), Stravinski se refería a la necesidad de someterse deliberadamente a un estilo. Lo que interesaba en ese momento al músico ruso, como corroboran sus palabras, no es el estilo específico sino el acto en sí de "sumisión" y restricción, algo que también exploró Falla al acotar tanto materiales como posibilidades instrumentales en las mencionadas obras, ambas pensadas para dos pequeños conjuntos instrumentales.

En Don Lindo, Halffter apuesta por la transparencia en las líneas y el equilibrio en la masa instrumental, restringida a las cuerdas y una discreta percusión que varía muy poco en carácter e intensidad a lo largo de la obra. Si hubiese que elegir a simple vista una cualidad de la obra ésta sería la concreción, lo que, si bien refleja una convicción estética personal, confirma, por otro lado, la fidelidad asumida al espíritu neoclásico. Es importante recordar un hecho que él mismo reconocería más tarde: a pesar de los distintos materiales sonoros utilizados en su obra futura, de las diferentes etapas de su carrera o de las transformaciones experimentadas por su lenguaje musical, siempre se movió dentro de esa estética.

Rodolfo Halffter muestra el mismo afán de restricción del que hablábamos antes; su elección instrumental resulta sumamente novedosa en el contexto de su tiempo. La plantilla de Don Lindo comprende una orquesta de cuerdas partida en dos secciones, es decir, dos orquestas paralelas separadas por la percusión (en la que alternan triángulo, castañuelas, tambor militar, plato suspendido, gran caja y tarola), orquestación a la que Halffter define como "en blanco y negro" y que constituye, de entrada, un voluntario alejamiento de tintes románticos o colores impresionistas.

algunos aspectos del magisterio de Claude Debussy sobre Manuel de Falla”, Cuadernos de Música Iberoamericana, vol. 4, I997, pp. 15-32. 
La presencia específica de ciertos recursos y elementos melódicos, rítmicos y de orquestación incluso permitiría aventurar la hipótesis de que la obra, en algunos pasajes, se hubiese concebido a partir de un pensamiento organístico. Que este instrumento intensamente vinculado con la práctica, la teoría y la interpretación de la música y las formas desarrolladas por la escuela española de los siglos XVII y XVIII haya sido un referente para Halffter en este trabajo es algo que no podría descartarse. No se oculta el hecho de que el autor se propusiera constreñir su planteamiento formal a partir de los asombrosos recursos técnicos y sonoros de esa etapa histórica. Por lo demás, la misma tendencia nos remite, hay que insistir en ello, hasta los llamados retornos al pasado, uno de los filones de la época que más certeramente apelan a los planteamientos básicos del neoclasicismo.

Varias razones explicarían lo anterior: ¿por qué decide Halffter, en cinco de los seis movimientos de que consta la obra, emplear un criterio de doble orquesta? ¿Intenta en realidad plantear un problema estructural? ¿Se trata acaso de un requerimiento acústico? ¿O simplemente responde a un interés específico por rescatar los procedimientos antifonales característicos de la policoralidad del barroco ${ }^{28}$ Las referencias organísticas no podrían estimarse aquí como un simple guińo de Halffter. ${ }^{59}$ Tampoco es fortuito que construyera su obra a partir de una sucesión de danzas, a la manera de una suite al estilo barroco, o que incluyera entre éstas la elaboración de una obra para órgano consagrada por la historia musical, a saber: los tres versillos del Sanctus del compositororganista Francisco Llusá (1687-1738), recogido en la Antología de organistas clásicos españoles. ${ }^{60}$

Cuando Rodolfo Halffter pensó en una división de los dos grupos instrumentales, sin duda consideraba las cualidades estereofónicas y espaciales de su

58. Nos basamos en las propias palabras de Halffter. En diversas ocasiones manifestó su absoluta fidelidad a la estética neoclásica. En febrero de I980, en un discurso leído en la Fundación Juan March de Madrid, refiere satisfecho que su "evolución” como compositor guarda siempre una sólida cohesión interna y permanece fiel a los principios estéticos a los que siempre se sintió ligado. Véase Ruiz Ortiz, op. cit., p. 60.

59. En ocasiones, el empleo de las dobles orquestas llega a ser muy complicado e incluso inútilmente costoso en términos económicos, ya que el resultado acústico en las modernas salas sinfónicas no es siempre el esperado. Algunos compositores lo han resuelto, en la práctica, imponiendo el divisi a las cuerdas o usando fórmulas que no precisen una división real, física, de la orquesta, tal como lo hace Béla Bartók en su Concierto para orquesta o Bach en La Pasión según san Mateo.

6o. Felipe Pedrell, Antología de organistas clásicos españoles, Madrid, UME, I908. 


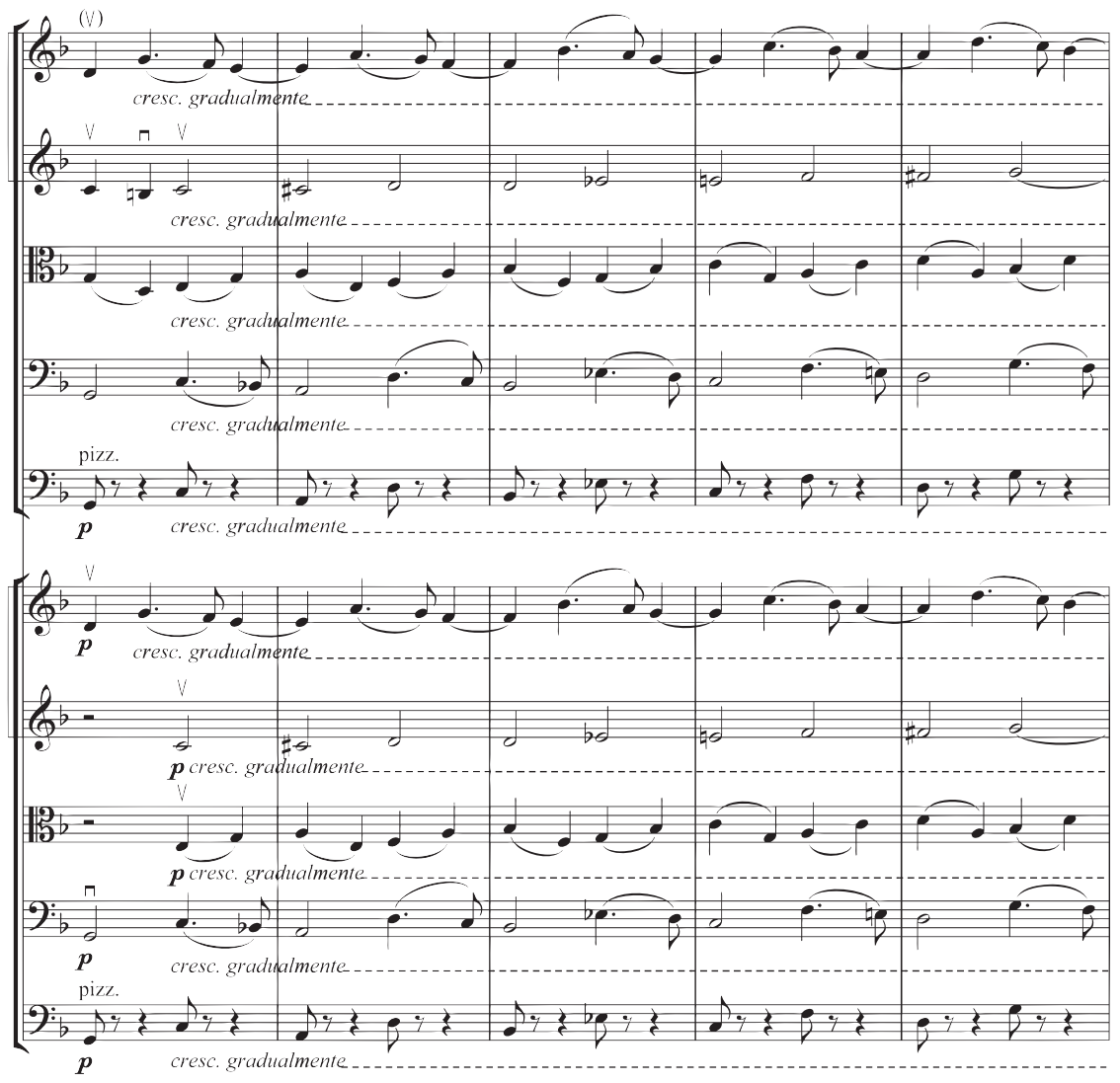

Ejemplo I: Don Lindo de Almería, fragmento de "Ceremonia nupcial", p. 27. Copia de Patricio Calatayud.

elección. En el transcurso de la obra los dos grupos pueden tocar al unísono o juntos materiales diferentes o bien realizar un juego antifonal, como ocurre particularmente en la "Danza final".

El empleo de las dos orquestas constituye un elemento tomado de la tradición de la policoralidad en la polifonía española de los siglos Xvi y Xviı. Pero es además un recurso efectivo para potenciar la densidad instrumental. Esto último se aprecia claramente en la misma "Ceremonia nupcial" (ejemplo I).

El tratamiento melódico predominante a lo largo de la obra es modal. En general, las melodías se mueven en un ámbito de cinco notas relacionadas entre 


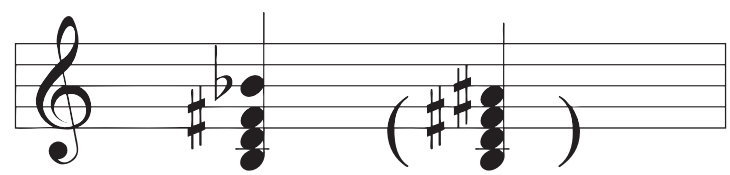

Ejemplo 2: Dibujo de Áurea Maya.

sí por grados conjuntos o con saltos más o menos cercanos. Pero el autor no se sujeta a determinados modos: se desplaza libremente a través de ellos. En cuanto a la construcción armónica, Rodolfo Halffter elabora, según el caso, planos armónicos tonales, modales y aparentemente bitonales. ${ }^{6 \mathrm{I}}$ Estos últimos, a partir de la superposición de dos acordes pertenecientes a ámbitos tonales distintos que, si bien sugieren dos tonalidades, no llegan a establecerse como tales. Al principio de la obra se sobreponen los acordes de si mayor con séptima mayor y si bemol mayor con séptima mayor. Por lo demás, la relación entre ambos acordes se da a través de una nota pivote: el la sostenido del primer acorde aparece en el segundo enarmonizado como si bemol (ejemplo 2).

El efecto sonoro a lo largo de toda la suite es el del traslado de la armonía polifónica a la elaboración instrumental. Salvo raras excepciones (como en compases aislados de la "Escena y danza segunda"), el ámbito de registro orquestal en que transcurre la obra se ubica en la región central. Esto indicaría que a Halffter no le interesó explotar los registros extremos de los instrumentos y prefirió sujetarse a las extensiones más comúnmente empleadas no sólo por la música popular sino por la tradición barroca y renacentista, donde es práctica común sustituir un instrumento por otro. Sin embargo, el diálogo tímbrico es sumamente rico, a pesar de tratarse de instrumentos de una

6I. De acuerdo con varios autores, el concepto de la "aparente politonalidad" que siguió Falla en determinadas obras proviene de las teorías acerca del sonido generador y sus resonancias, desarrolladas por Louis Lucas (I8I6-I863). Resultan iluminadores al respecto los textos de Chris Collins, "Manuel de Falla. L'Acoustique Nouvelle and Natural Resonance: a Myth Exponed", Journal of The Royal Music Association, vol. 22, núm. I28, mayo de 2003, y de Nancy Lee Harper: capítulo II, "Louis Lucas", en Manuel de Falla. His Life and Music, Maryland, Scarecrow Press, 2005, pp. I88-207. Por su parte, Michael Christophoridis conecta los mismos hallazgos de Falla, respecto a las propiedades de la serie acústica, con la obra de Debussy, puesto que el compositor francés generaba muchas de sus prácticas armónicas a partir de ese principio. Véase su artículo "De $L a$ vida breve a Atlántida: algunos aspectos del magisterio de Claude Debussy sobre Manuel de Falla", publicado en Cuadernos de Música Iberoamericana, op. cit., vol. 4. 
misma familia. Por lo demás, el autor no renuncia al empleo de otros elementos más cercanos a la modernidad como son los armónicos, propios de los instrumentos de cuerda (que en este caso no podrían remplazarse por otros). Esta particularidad instrumental contribuye a situar la obra en un espacio temporal más contemporáneo. ${ }^{62}$ En el siguiente ejemplo (3) los sonidos armónicos del contrabajo sirven como nota pedal.

En el inicio de la "Danza tercera", mientras los sonidos armónicos en el contrabajo sirven nuevamente como nota pedal al pasaje, los violines segundos (a distancia de octava en una y otra secciones) contribuyen a dar un efecto colorístico y al mismo tiempo una pincelada jocosa, humorística.

No obstante su voluntaria intención anticromática, la brillantez del trabajo melódico en determinados pasajes contradice ese principio en que insisten ambos autores. Véase, por ejemplo, el inicio de la "Danza tercera" (sección de cuerdas del primer grupo instrumental), donde el autor separa sus registros hasta tres octavas para hacer sonar una melodía plena de tensión y lirismo.

La obra presenta una articulación rítmica sumamente variada. Uno de los ritmos dominantes, sin embargo, es el constituido por el compás binario (con subdivisión ternaria) en sus distintas combinaciones o, lo que es lo mismo, ritmo de sesquiáltera. Esta fórmula se muestra con gran claridad en la primera danza y en especial en la "Danza cuarta", en que prevalece de principio a fin (ejemplo 4).

El hecho de que esta alternancia aparezca en sus diferentes combinaciones de manera recurrente a lo largo de la suite ofrece un elemento más que enlaza la obra con la tradición popular espańola. Conviene recordar que muchos tipos de danzas españolas se basan en esta clase de alternancias rítmicas. No obstante, el compás $2 / 4$ en la "Danza final" responde al empeño de Halffter de apoyar el carácter marcadamente rítmico de la danza de recorrido breve (el pasodoble se escribe en $2 / 4$; ejemplo 5).

La única vez que Halffter emplea en la obra el compás de 4/4 lo hace para responder a un fraseo de carácter ceremonioso, cual corresponde a la indicación Andante affetuoso. Hay que hacer notar la carencia de indicaciones metronómicas, pues el compositor se basa exclusivamente en indicaciones de tempo (ejemplo 6).

62. Como es bien sabido, el empleo de los sonidos en armónicos se hizo más frecuente conforme avanzaba el siglo $\mathrm{xx}$, hasta constituirse en uno de los recursos característicos de muchas obras de la llamada vanguardia. 


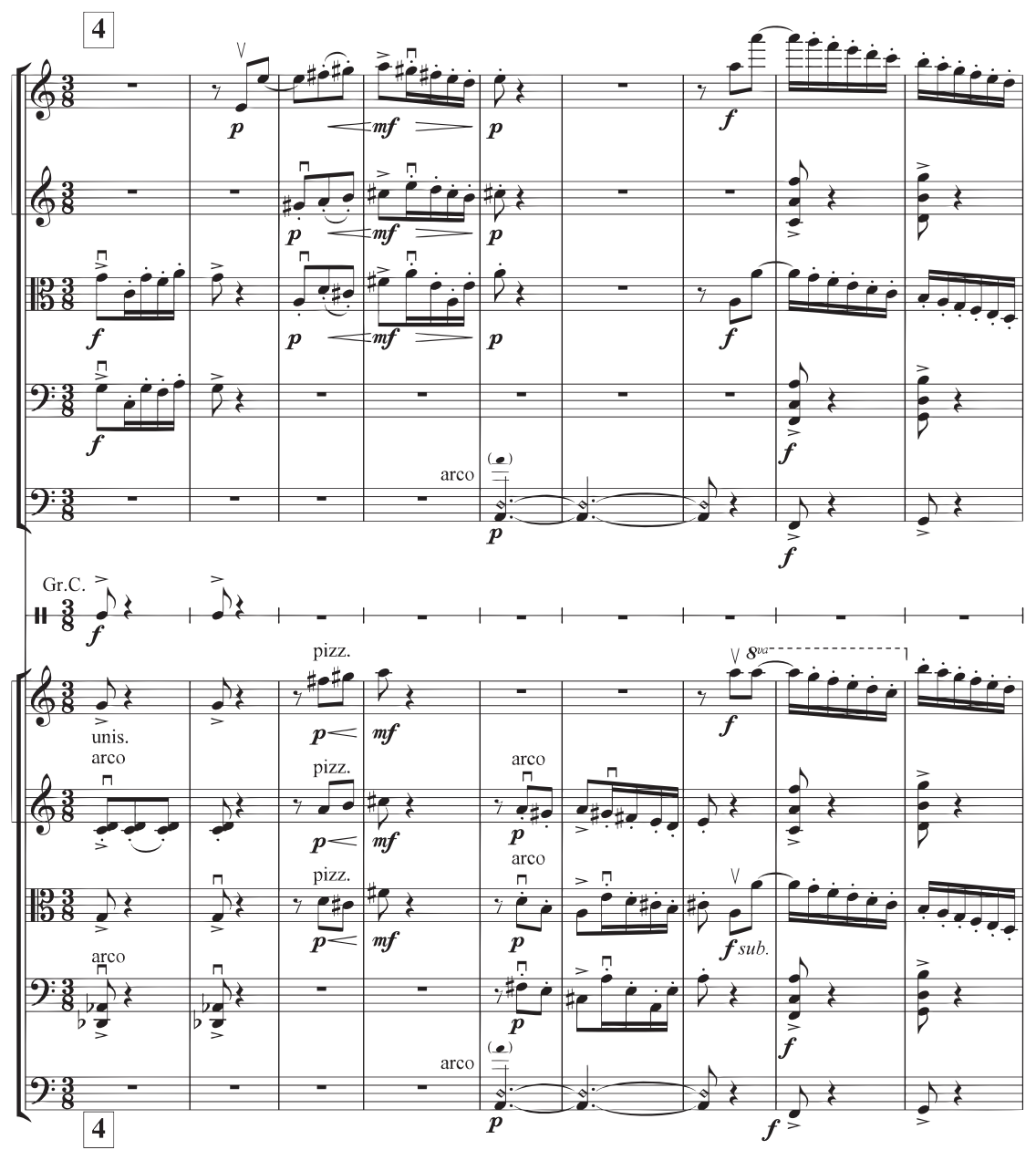

Ejemplo 3: Don Lindo de Almería, fragmento de "Escena y danza segunda", p. I I. Copia de Patricio Calatayud.

3
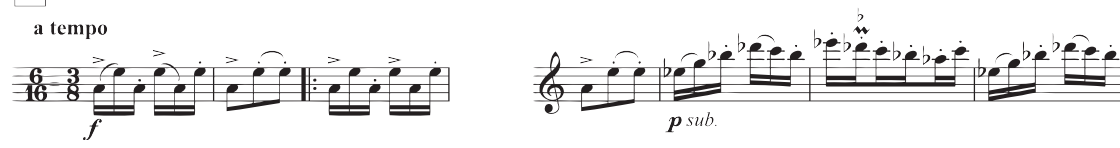

Ejemplo 4: Don Lindo de Almería, fragmento de "Introducción y danza primera", p. 5. Copia de Patricio Calatayud. 


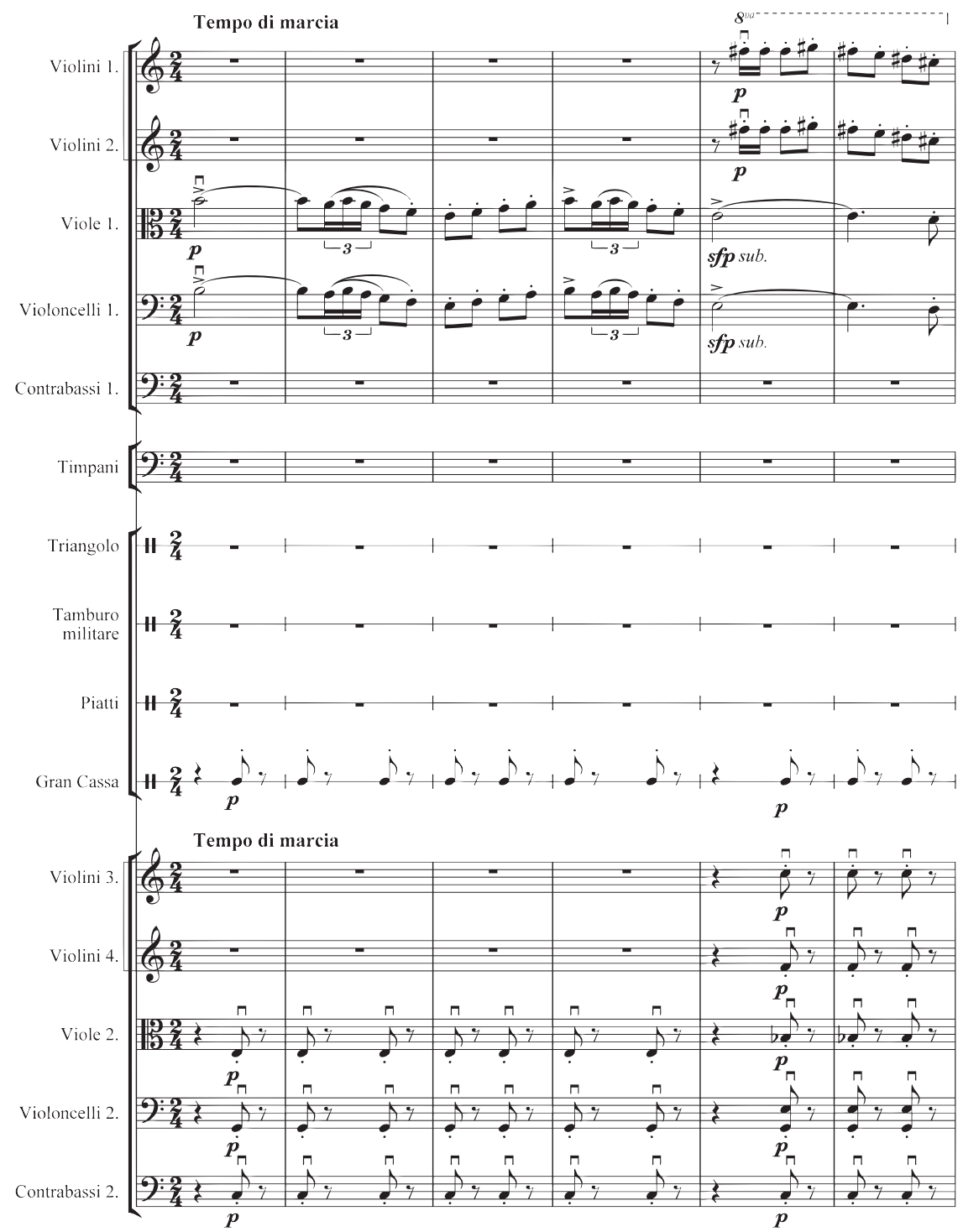

Ejemplo 5: Don Lindo de Almería, "Danza final”, p. 36. Copia de Patricio Calatayud. 
96

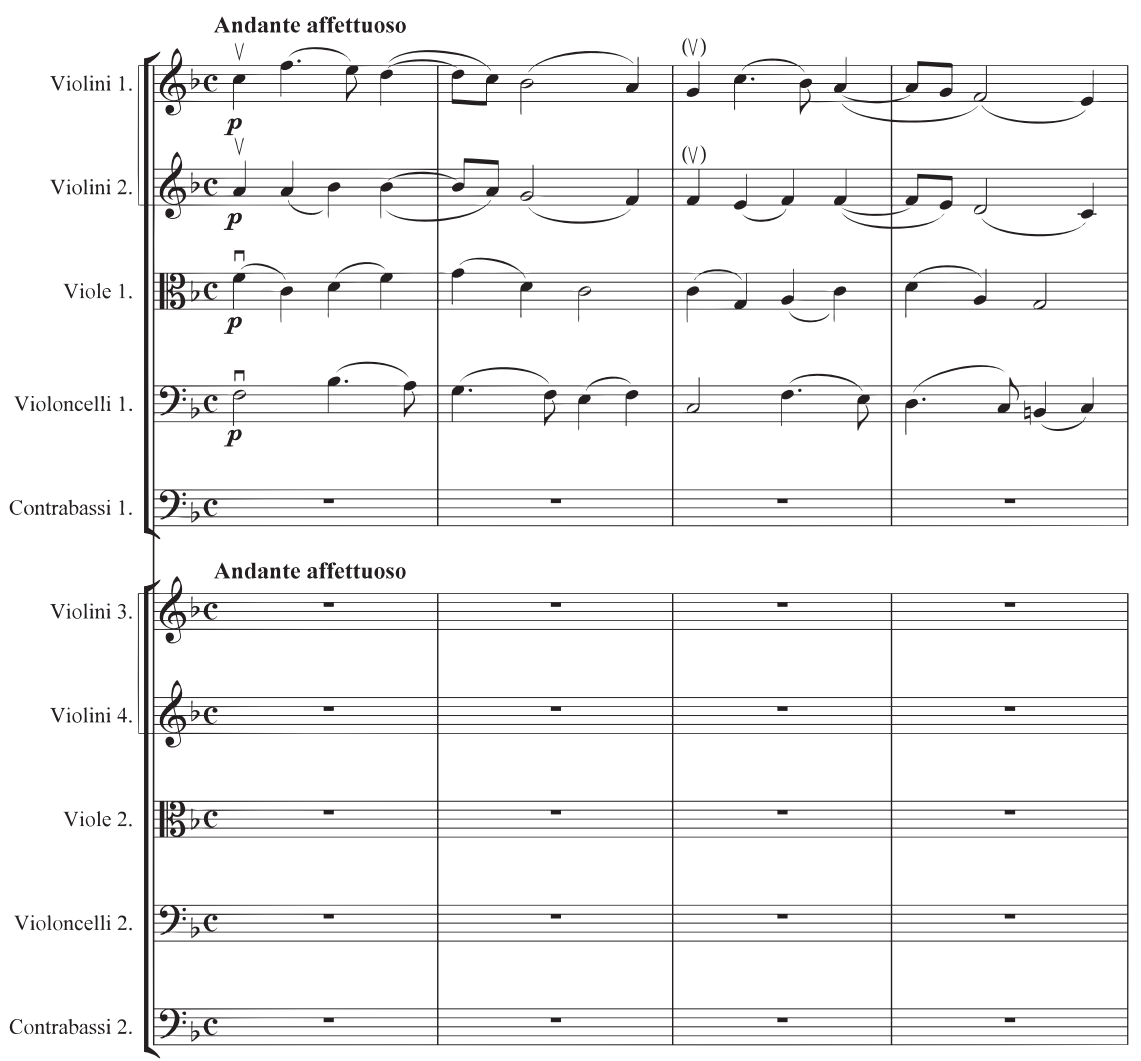

Ejemplo 6: Don Lindo de Almería, "Ceremonia nupcial”, p. 26. Copia de Patricio Calatayud.

Las tres distintas armaduras de la "Escena y danza segunda", que a primera vista estarían definiendo tres distintas tonalidades, obedecen, en cambio, al interés de facilitar la escritura. Halffter utiliza aquí las distintas armaduras como un método de transposición. Para abordar este problema con mayor precisión, debemos referirnos al planteamiento melódico propuesto por Halffter para esta "Escena y danza segunda", basado en la escala modal frigia, transportada a mi bemol (ejemplo 7).

El primer motivo, en los bajos, con que empieza la "Escena y danza segunda" se basa en el motivo inicial de la primera danza. Se trata de un motivo ascendente, a base de tonos enteros, que tocan los violonchelos y los contrabajos del primer grupo instrumental, constituido por las notas segunda, tercera, 
Escala modal frigia

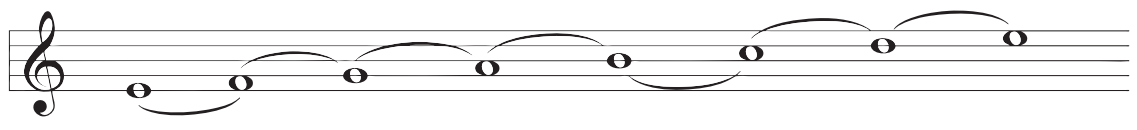

Transporte a mi b

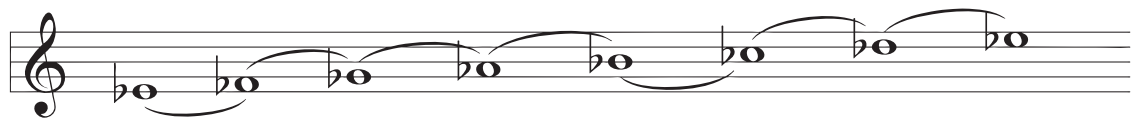

Ejemplo 7: Dibujo de Áurea Maya.

cuarta y quinta de la escala frigia. El motivo descendente de la viola, aunque actúa como un espejo del motivo anterior, en realidad no se basa en el mismo modo frigio, sino en una escala de mi bemol que podría interpretarse como un modo mayor (es preciso resaltar el contraste entre el modo frigio, cuya estructura interválica es la de una escala menor — por la tercera menor-, y el que se produce con lo que parece ser un mi bemol) y cuya réplica, al espejo, tienen a su cargo las violas en un piano cantabile (ejemplo 8).

Vayamos ahora al compás número 5 de la misma "Escena y danza segunda". Pese a la complejidad de su escritura y su aparente politonalidad, que, como hemos visto, no es tal, el pasaje constituye una sencilla sucesión paralela de acordes de séptima de dominante con un interés meramente colorístico. Este recurso, tan empleado por Stravinski en numerosas ocasiones, es también característico del órgano barroco y consiste en la capacidad de estos instrumentos de realizar "duplicaciones" del sonido fundamental a distancia de octava, quinta y tercera mediante la superposición de sus distintos registros. Este procedimiento potencia el sonido y en cierto modo modifica el resultado tímbrico al reproducir la columna de sonidos armónicos a partir de un sonido fundamental. Halffter emplea un recurso similar, sólo que enriquece el procedimiento al añadir la séptima a las duplicaciones.

El que nuestro autor optara por escribir una sucesión de acordes de séptima sin seguir de modo puntual los intervalos de la escala modal — que guía melódicamente todo este episodio del ballet — se explica, como decíamos, por razones de colorido armónico. Este procedimiento resulta menos oscuro que el de la segunda opción, es decir, el enlace de los mismos acordes de séptima a 
Andante calmo

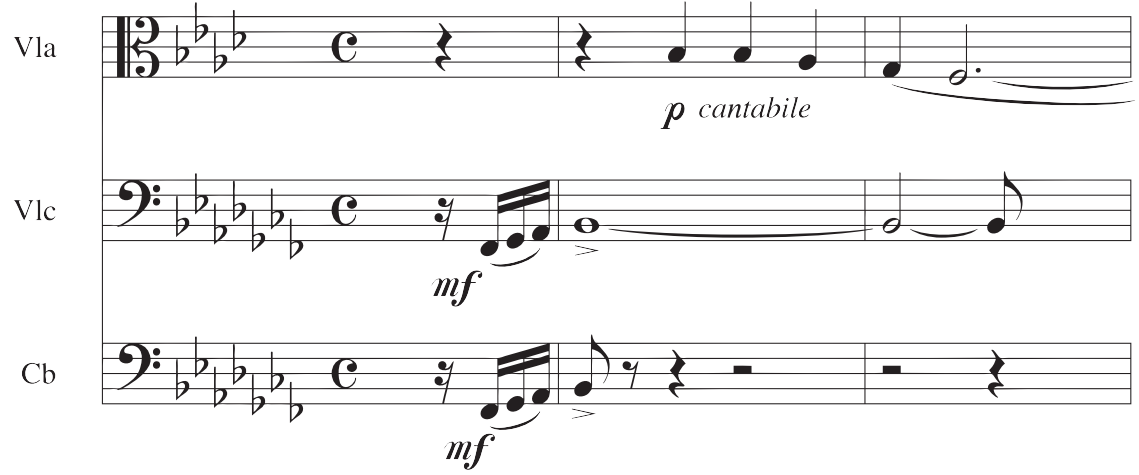

Ejemplo 8: Dibujo de Áurea Maya.

través de las notas descendentes de la escala modal; ese mismo tipo de "doblajes" es una opción que Stravinski aprovecha en un pasaje de la Consagración (aunque ahí respeta la sucesión de las notas de la escala modal elegida). Por lo demás, la incorporación de las castañuelas contribuye a crear en este punto el ambiente de gran animación que busca Halffter y que caracteriza esta segunda danza (ejemplo 9).

La estructura formal de la "Danza tercera" es típicamente ternaria. Se inicia con un ostinato de los violines en armónicos que crea una textura sobre la cual aparece la melodía de gran lirismo que llena toda la primera sección de la danza (24 compases). La melodía de esta sección A, escrita en el modo eólico (o lo que es lo mismo en el modo menor natural), muestra cierta ambigüedad modal en pasajes que tienden hacia los grados cuarto y quinto de la escala. El tratamiento armónico también se acerca a la propuesta modal, a diferencia de la armonía empleada por Halffter en la "Danza primera". Una suerte de codeta a base de la tradicional fórmula cadencial (I 6/4 - IV- V- I) da paso a la sección B: un canon a la octava (nuevamente planteado a partir de cinco notas: cuatro compases en re más cuatro en la). En los siguientes ocho compases una melodía en re repite elementos antes propuestos en el canon y se hace acompañar de un ostinato en la para apoyar, con la percusión, la melodía principal.

En la "Danza cuarta" desaparece por completo cualquier elemento de percusión. Sus temas y el tratamiento contrapuntístico denotan un perfil señaladamente dieciochesco: es el pasaje de la obra que presenta más elementos neoclásicos (ejemplo ıo). 


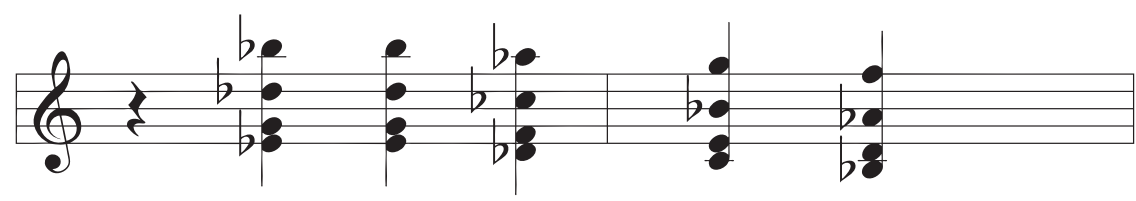

Ejemplo 9: Dibujo de Áurea Maya.

La "Ceremonia nupcial", de carácter solemne y contenido, no obstante su expresividad, es una elaboración, como se dijo antes, de los tres versillos de Llusá. Se trata de un episodio contrapuntístico de particular desnudez y lirismo formado por dos secciones contrastadas; es el capítulo de la obra en que se ponen en juego, de manera más fidedigna, las técnicas del alto barroco: imitaciones, pasajes fugados y canónicos, además de progresiones, así como un tratamiento armónico claramente tonal. Este procedimiento compositivo (la elaboración), muy al uso en creadores vinculados con la estética neoclásica, consiste en "replantear", es decir, en utilizar, a partir de nuevos términos, los procedimientos establecidos por la tradición. Al recoger en la composición una forma consagrada, Rodolfo Halffter sigue sin duda a Stravinski. El creador no se encuentra - apunta el músico ruso- en una circunstancia donde su propia personalidad esté limitada; por el contrario, "está en una situación más desprendida y avanza más cuando se mueve dentro de los límites definidos de una obra ya creada". ${ }^{63}$

A diferencia de lo que ocurre en la "Danza final" —el pasaje más interesante para las percusiones-, el papel básico de la percusión en el curso de la obra consiste sólo en reforzar, cuando así lo elige el autor, algunos aspectos rítmicos: nunca se usa de manera autónoma. Uno entre otros ejemplos de esto lo encontramos en la "Danza y escena quinta"; aquí se percibe la presencia más que discreta de la percusión, cuya tarea consiste de nuevo en marcar, tímidamente, frases breves o cadencias. Por lo demás, el empleo de la tarola en la "Danza final" refrenda el talante escénico de la pieza.

Como ya indicábamos, el acercamiento de Halffter al canto popular en esta obra fue, en sus propias palabras, a la vez irónico e intelectual. Lo primero, porque las referencias a las danzas y los cantares populares aparecen desvirtuadas, desencajadas de su línea original o, dado el caso, desmenuzadas para evitar ser reconocidas. Como bien indica el crítico José Antonio Alcaraz, en su

63. Igor Stravinski, Crónica[s] de mi vida, Barcelona, Nuevo Arte Thor, 1985, p. 42. 

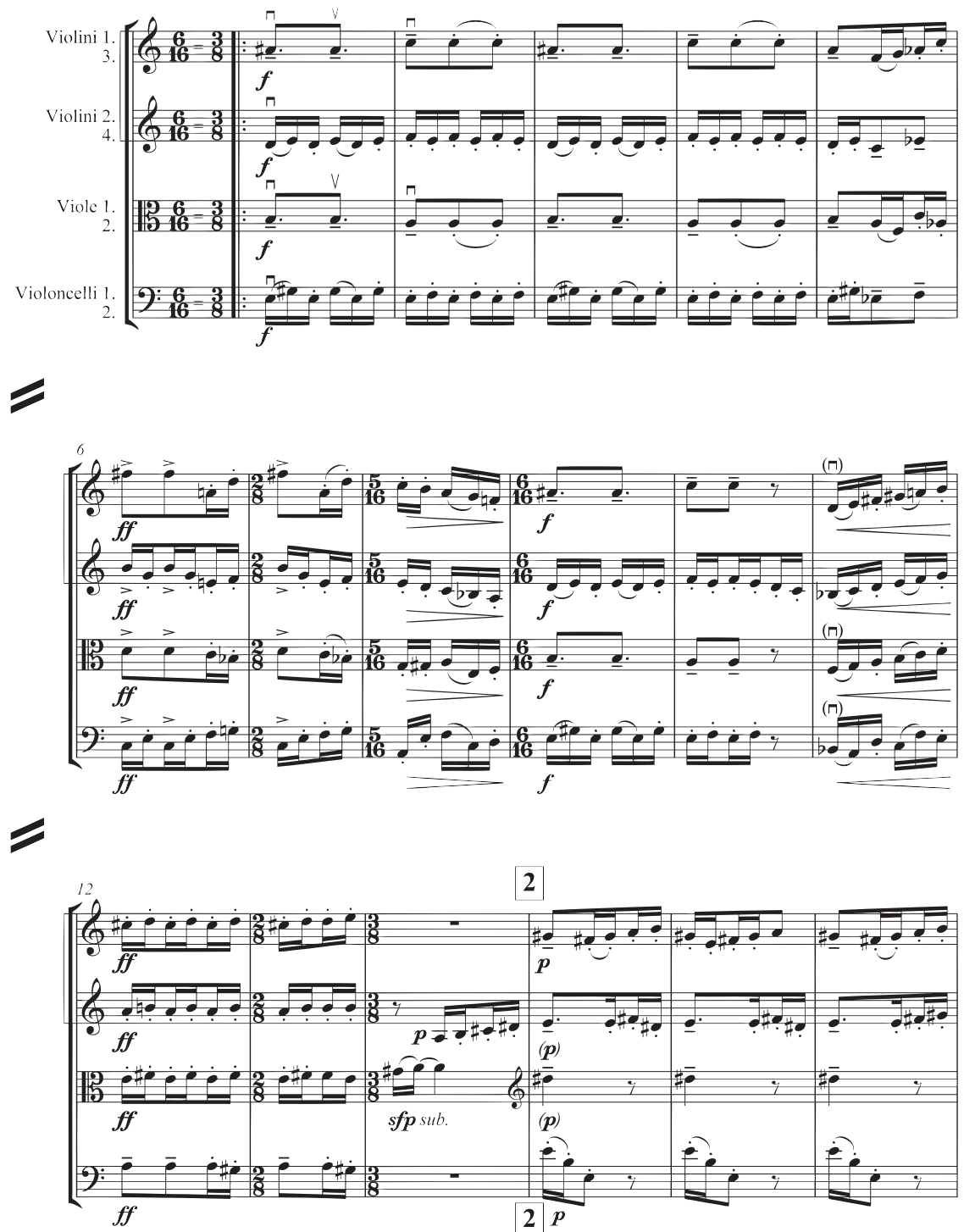

Ejemplo ro: Don Lindo de Almería, "Danza cuarta", pp. 32 y 33. Copia de Patricio Calatayud. 
concepción musical Halffter reafirma una voluntad, manifiesta a lo largo de la obra, de mantenerse al margen de cualquier nacionalismo consciente. ${ }^{64}$ Referencias poco perceptibles remiten sólo al especialista al Cancionero popular de Pedrell, suerte de Biblia para Halffter como para su generación. Jorge Velazco advierte algunas citas de la conocida melodía popular recogida por Pedrell: “ $¡ Y a$ se murió el burro!", pasaje que sirve de puente hacia la penetrante y robusta apoteosis final. ${ }^{65}$ En esta última escena convergen una serie de elementos aparecidos en otras danzas y escenas; temas simples, sin rebuscamiento (;reminiscencias del Scarlatti español?), que se suceden por yuxtaposición y no a través de largos desarrollos temáticos, matiz que quizá indica cierto paralelismo con la pintura cubista donde se aplica el mismo principio.

Que hayan transcurrido más de quince años entre la representación escénica de Don Lindo de Almería en la ciudad de México y su publicación por Ediciones Mexicanas de Música nos impele a plantear una última reflexión: ¿qué tanto ennoblecieron el imaginario musical de Rodolfo Halffter los verdes maizales de este país? Es difícil predecir la respuesta. Lo cierto es que al paso del tiempo aquellas escenas andaluzas que dieron vida a una de las más significativas partituras del autor se convirtieron en pieza sinfónica infaltable de los repertorios mexicanos.

\section{Ediciones de música}

Rodolfo Halffter, Don Lindo de Almería. Suite del ballet, México, Ediciones Mexicanas de Música, 1978. \$ै

64. José Antonio Alcaraz, La música de Rodolfo Halffter, Cuadernos de Música, nueva serie, México, Universidad Nacional Autónoma de México, núm. 4, 1977.

65. Jorge Velazco, "La cromoterapia costumbrista de Rodolfo Halffter", Pauta. Cuadernos de Teoría y Crítica Musical, núm. 22, abril-junio de 1987. 